\title{
Study of heat shielding qualities of brick wall angle with additional insulation located on the outside fences
}

\author{
Oleg Yurin ${ }^{1}$, and Tatiana Galinska ${ }^{1 *}$ \\ ${ }^{1}$ Poltava National Technical Yuri Kondratyuk University, Department of Civil Engineering, \\ Pershotravnevyi Avenue, 24, Poltava, 36011, Ukraine
}

\begin{abstract}
The results of theoretical studies of heat-shielding properties of the angle of external wall a residential building are presented. The brick wall thickness of $510 \mathrm{~mm}$ was considered. The studies were performed for the I-st temperature zone of Ukraine. Heat insulation was located on the external side of enclosure. Thermal protection problems of the angle are consideration of the impact of heat-conductive inclusion on adjusted heat transfer resistance of enclosure. Conductive inclusion on the external angle area is its configuration. An additional layer of insulation in the angle area is necessary to use for bringing the level of thermal protection of angle area to the standards. The results of calculations of two-dimensional temperature fields were used for the analysis of thermal protection. Two options for additional insulation were studied. The first option: continuous strip insulation covering the external wall angle. Another one provides division of additional insulation layer into two parts and displacement them from the angle within the design scheme. Studies were performed for different thickness of additional insulation. There was additionally taking into account the value of insulation displacement from the angle for the second option. The optimal location and size of additional insulation were determined. The minimum amount of additional insulation under which the thermal protection requirements are performed was accepted like optimality criterion.
\end{abstract}

\section{Introduction}

One of the main tasks of designing external fencing structures of residential buildings is to provide a normalized level of heat shield. Herewith in the determination of thickness of the insulation in external walls the seats with heat conductive inclusions, in which the level of heat shield usually less than in areas without them are ignore. Areas with heat conductive inclusions include the following: place of relying on the wall of overlap constructions or balcony plate, walls abutment to windows or balcony doors, external wall angle. Ignoring the properties of these areas leads to higher overall heat loss through external fencing structures. Besides high heat, losses in these places there are such negative phenomena as

\footnotetext{
* Corresponding author: galinska@i.ua
} 
lowering the temperature of the inner wall surface and increase amplitude of oscillations the temperature on this surface. Increasing of heat shielding properties of external wall angle is possible through its additional insulation.

\subsection{Review of the recent studies and publications}

Work of many authors dedicated to issue of increasing heat shielding properties of angles to the requirements of norms [1-3]. So, in [4-6] described variants of additional insulation on the external side by increasing the thickness of the primary insulation in the area of building angle. The option of internal insulation is also considered in this article. The variants of additional insulation of frame-monolithic buildings angle are considered in [7]. The impact of the relative position of the external building angle and window aperture on the temperature of the internal surface angle was considered in [8].

\subsection{Assignment aspects of the general problem unsolved earlier}

In publications dealing with the study of ways to improve the heat shielding properties of angle to the heat transfer norms, the use continuous additional layer of insulation located on the external surface of the fence was proposed. The option of separation of additional insulation into two parts and displacement it from angle within the design scheme is not considered. No recommendation was given concerning the ratio of the thickness to length of the additional insulation layer under which material expenses will be minimal.

\subsection{Setting objectives}

The objective of this work was determining the optimal location and the possible minimum size of additional insulation in the external brick wall angle under which heat shielding conditions will be performed. Minimal required capacity of additional insulation adopted like criterion of optimality.

\section{Basic material and results}

The construction of a brick wall with external insulation is shown in Fig. 1. Fencing layers located on the external side insulation have no significant effect on the heat-shielding properties of the fence due to little thickness. That is why in the calculations they are changed to a layer of cement-sand mortar with the thickness of $5 \mathrm{~mm}$. A leveling layer of cement-sand mortar between the insulation and brickwork the thickness of $5 \mathrm{~mm}$ is added.

Characteristics of materials of the fencing structure layers are shown in Table 1.

Table 1. Characteristics of materials of the fencing structure layers.

\begin{tabular}{|l|c|c|c|}
\hline \multicolumn{1}{|c|}{ Fencing structure layers } & $\begin{array}{c}\text { Density, } \\
\mathrm{kg} / \mathrm{m}^{3}\end{array}$ & $\begin{array}{c}\text { Thickness, } \\
\mathrm{m}\end{array}$ & $\begin{array}{c}\text { Thermal } \\
\text { conductivity, } \\
\mathrm{W} / \mathrm{m} \cdot \mathrm{K}\end{array}$ \\
\hline Sand-lime mortar & 1800 & 0.02 & 0.93 \\
\hline Brick & 1800 & 0.51 & 0.81 \\
\hline Cement-sand mortar & 1600 & 0.005 & 0.81 \\
\hline SUPERROCK Basalt mineral wool & 135 & 90 & 0.035 \\
\hline Cement-sand mortar & 1600 & 0.005 & 0.81 \\
\hline
\end{tabular}




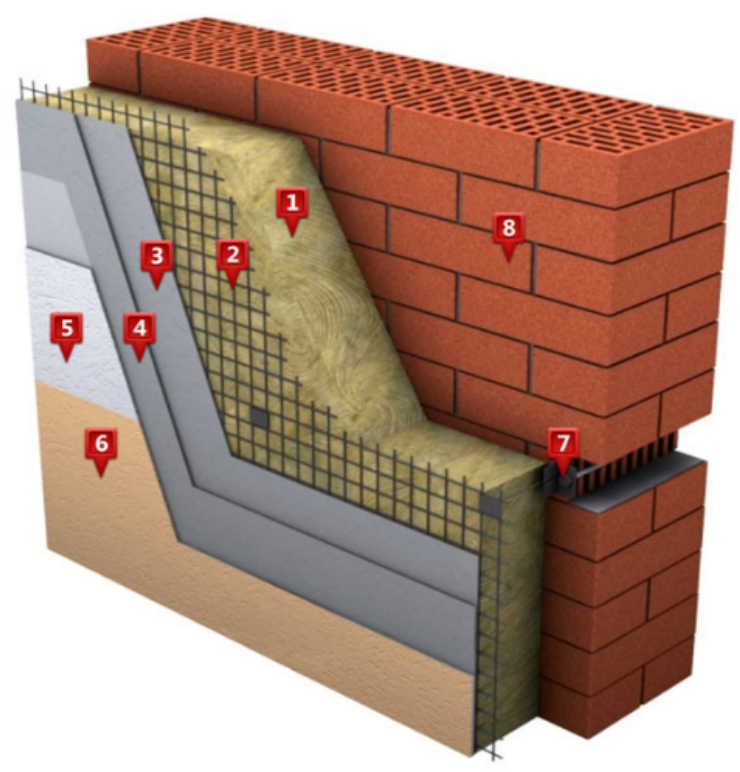

Fig. 1. The construction of a brick wall with external insulation. 1- insulation; 2 - steel net; 3 - primer coat; 4 - leveling coat; 5 - decorative plaster; 6 - facade paint; 7- steel rock bolting; 8 - brick wall.

The thickness of the base layer of insulation defined by the heat engineering calculation for residential building in the I-th temperature zone is $90 \mathrm{~mm}$.

Adjusted heat transfer resistance of external angle is determined on the basis of temperature field calculations. Options for offered additional insulation angle are compared with the scheme provided by A. Prischenko in [4-5] (Fig. 2).

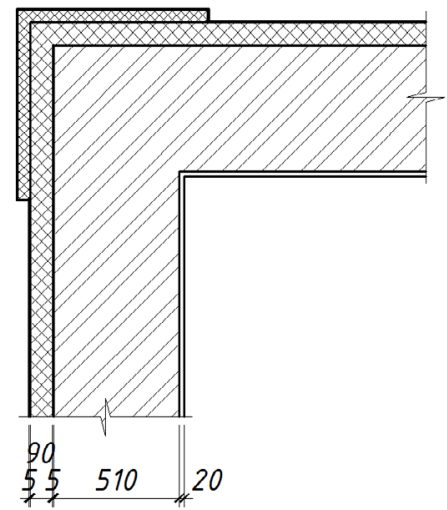

Fig. 2. Options for additional insulation angle according to the source [4-5].

Studies have shown that the minimum capacity of additional insulation (to meet the requirements of heat shield) will be determined for thickness of $40 \mathrm{~mm}$ and length (from the angle) of $1840 \mathrm{~mm}$. In other words, additional insulation length is close to the length of the design scheme. The minimum capacity of additional insulation was 0.14 to $1 \mathrm{~m}$ high of the wall. The temperature field of angle for this option is shown in Figure 3.

For these dimensions of additional insulation:

- $\quad R_{\Sigma \text { red }}=3.305 m^{2}-W K>R_{q \text { min }}=3.3 m^{2}-W K$; 
- $\Delta t_{\text {red }}=1.5^{\circ} \mathrm{C}<\Delta t_{s . h}=4{ }^{\circ} \mathrm{C}$;

- $\tau_{\text {in.min }}=16.9^{\circ} \mathrm{C}>t_{\text {dew }}=10.7^{\circ} \mathrm{C}$.
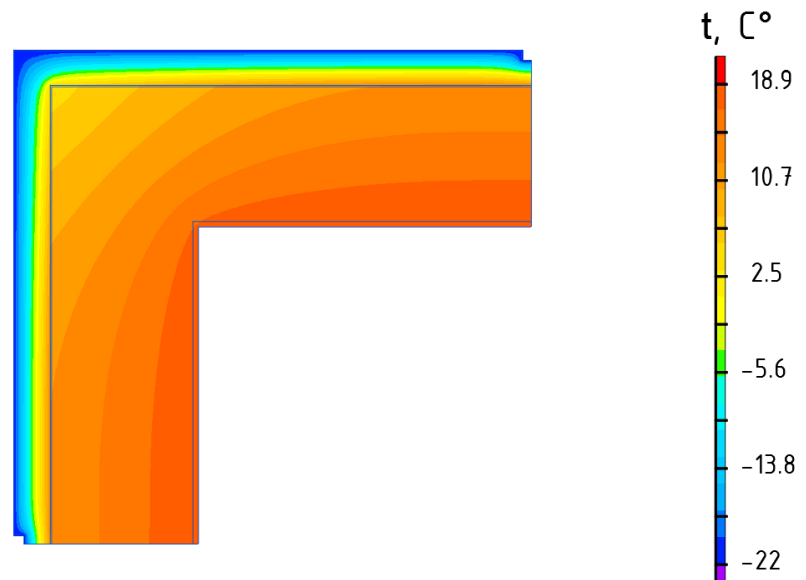

Fig. 3. The temperature field of angle with a solid layer of additional insulation.

The proposed option of additional insulation with a shift from the wall angle is shown in Figure 4.

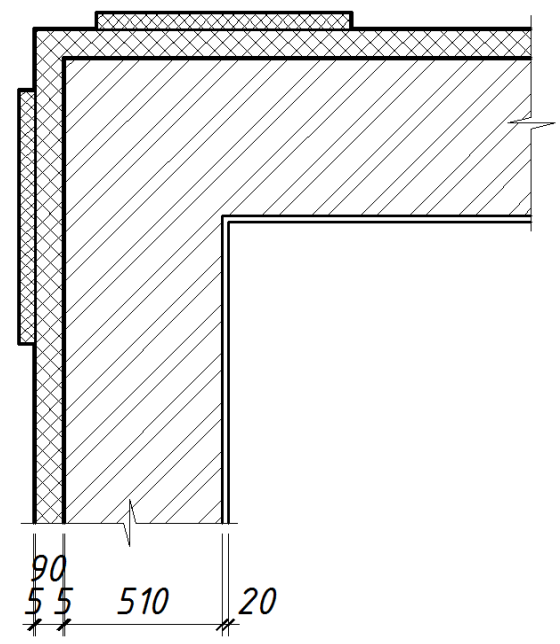

Fig. 4. The proposed option of additional insulation with a shift it from the wall angle.

The options of additional insulation layer with a thickness of $60 \mathrm{~mm}, 50 \mathrm{~mm}, 40 \mathrm{~mm}$ and $30 \mathrm{~mm}$ were considered.

The length of the design scheme is not enough to meet the requirements of heat shield at a thickness of additional insulation $30 \mathrm{~mm}$.

The last option of the location of additional insulation, at each of its thickness, is when it coincides with the edge of design scheme.

As shown in Table 2, the optimal option (minimum capacity of insulation) was additional insulation angle with layer thickness of $40 \mathrm{~mm}$, a length of $1700 \mathrm{~mm}$ at its location on the edge of design scheme (at a distance of $160 \mathrm{~mm}$ from the wall angle). 
Table 2. The results of the study of heat-shielding properties of the angle by the proposed scheme, at a thickness of additional insulation $50 \mathrm{~mm}$.

\begin{tabular}{|c|c|c|c|c|c|c|}
\hline Scheme & 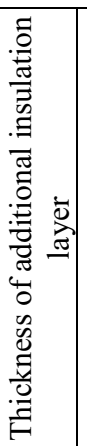 & $\begin{array}{l}\text { Distance } \\
\text { from } \\
\text { angle, } \\
\text { mm }\end{array}$ & $\begin{array}{c}\text { Length of } \\
\text { additional } \\
\text { insulation, } \\
\mathrm{mm}\end{array}$ & $\begin{array}{l}\text { Adjusted heat } \\
\text { transfer } \\
\text { resistance }\end{array}$ & $\begin{array}{c}\text { Capacity of } \\
\text { additional } \\
\text { insulation, } \mathrm{m}^{3}\end{array}$ & $\begin{array}{c}\text { Percentage } \\
\text { of capacity } \\
\text { of } \\
\text { additional } \\
\text { insulation } \\
\text { by the } \\
\text { scheme } \\
\text { according to } \\
\text { the source } \\
{[4,5], \%}\end{array}$ \\
\hline $\begin{array}{c}\text { According } \\
\text { to the } \\
\text { source } \\
{[4,5]}\end{array}$ & 40 & 0 & 1830 & 3.305 & 0.1448 & 100 \\
\hline \multirow{26}{*}{ 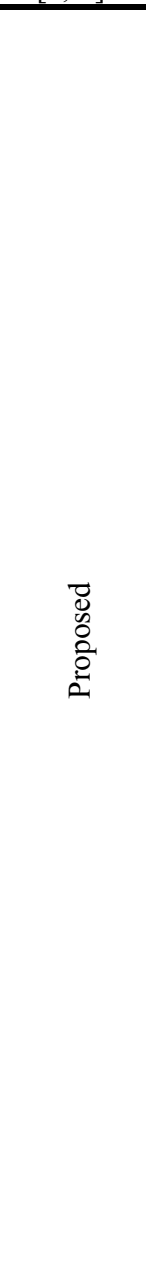 } & \multirow{13}{*}{60} & 50 & 1450 & 3.308 & 0.174 & 120 \\
\hline & & 100 & 1410 & 3.311 & 0.1692 & 117 \\
\hline & & 150 & 1380 & 3.307 & 0.1656 & 114 \\
\hline & & 200 & 1360 & 3.308 & 0,1632 & 113 \\
\hline & & 250 & 1340 & 3.306 & 0.1608 & 111 \\
\hline & & 300 & 1320 & 3.304 & 0.1584 & 109 \\
\hline & & 350 & 1300 & 3.304 & 0.156 & 108 \\
\hline & & 400 & 1290 & 3.305 & 0.1548 & 107 \\
\hline & & 450 & 1270 & 3.3005 & 0.1524 & 105 \\
\hline & & 500 & 1260 & 3.305 & 0.1512 & 104 \\
\hline & & 550 & 1250 & 3.307 & 0.15 & 104 \\
\hline & & 600 & 1230 & 3.3007 & 0.1476 & 102 \\
\hline & & 660 & 1220 & 3,305 & 0,1464 & 101 \\
\hline & \multirow{10}{*}{50} & 50 & 1580 & 3.3004 & 0.158 & 109 \\
\hline & & 100 & 1540 & 3.3007 & 0.154 & 106 \\
\hline & & 150 & 1510 & 3.301 & 0.151 & 104 \\
\hline & & 200 & 1490 & 3.303 & 0.149 & 103 \\
\hline & & 250 & 1470 & 3.303 & 0.147 & 102 \\
\hline & & 300 & 1450 & 3.301 & 0.145 & 100 \\
\hline & & 350 & 1440 & 3.307 & 0.144 & 99 \\
\hline & & 400 & 1420 & 3.304 & 0.142 & 98 \\
\hline & & 450 & 1400 & 3.302 & 0.14 & 97 \\
\hline & & 480 & 1390 & 3.303 & 0.139 & 96 \\
\hline & \multirow{3}{*}{40} & 50 & 1780 & 3.303 & 0.1424 & 98 \\
\hline & & 100 & 1740 & 3.304 & 0.1392 & 96 \\
\hline & & 160 & 1700 & 3.302 & 0.136 & 94 \\
\hline
\end{tabular}

The temperature field of option for the location of additional insulation shown in Figure 5. 


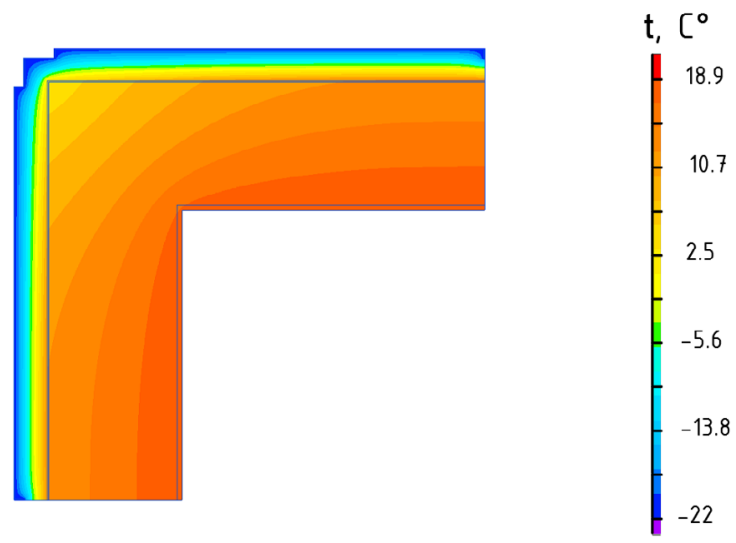

Fig. 5. The temperature field of wall area with additional insulation length of $1700 \mathrm{~mm}$ and thickness of $40 \mathrm{~mm}$ at a distance of $160 \mathrm{~mm}$ from the angle (on the edge of design scheme).

A graph of temperature distribution on internal surface of the wall area is shown in Figure 6.

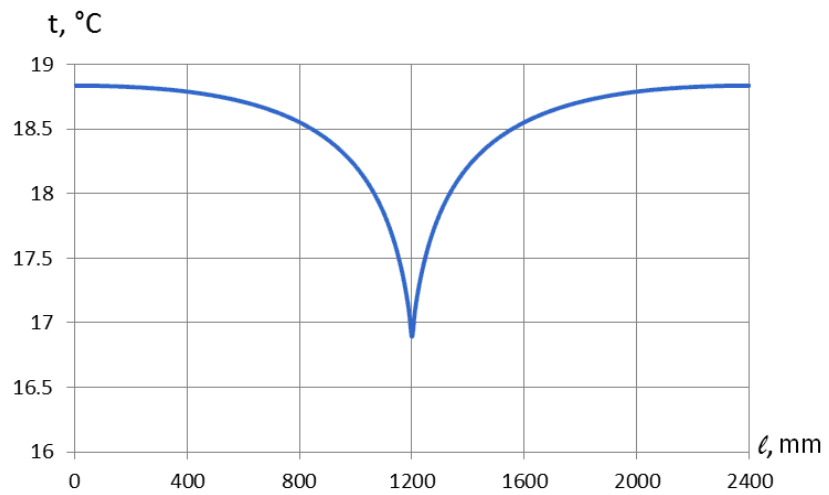

Fig. 6. A graph of temperature distribution on internal surface of the wall area with additional insulation length of $1700 \mathrm{~mm}$ and thickness of $40 \mathrm{~mm}$ at the distance of $160 \mathrm{~mm}$ from the angle (on the edge of design scheme).

At these sizes and location of additional insulation:

$R_{\Sigma \text { red }}=3.302 \mathrm{~m}^{2}-W K>R_{q \min }=3.3 \mathrm{~m}^{2}-W K$;

$\Delta t_{\text {red }}=1.5^{\circ} \mathrm{C}<\Delta t_{\text {s.h }}=4{ }^{\circ} \mathrm{C}$;

$\tau_{\text {in.min }}=16.9^{\circ} \mathrm{C}>t_{\text {dew }}=10.7^{\circ} \mathrm{C}$.

All heat shielding requirements are fulfilled.

\section{Conclusions}

With decreasing the thickness of additional insulation layer its capacity needed to meet the heat shielding requirements is decreases.

With displacement of additional insulation layer from the wall angle, its capacity necessary to meet the heat shielding requirements is decreases.

The lowest capacity of additional insulation needed to meet the heat shielding requirements is observed at its location on the edge of design scheme.

The lowest capacity of additional insulation will be at its least possible thickness and 
location on the edge of design scheme.

For the considered construction of external wall insulation and applied insulation according to the scheme when it consists of two parts shifted from the wall angle, decreasing of the capacity of additional insulation is $6 \%$ compared with the scheme when a continuous strip insulation covering angle.

\section{References}

1. DBN V.2.6-31:2006. Konstruktsiyi budinkiv i sporud. Teplova izolyatsiya budivel / Minbud Ukrayini. Kiev, (2006)

2. A.E Piir., O.A Kozak., V.B Kuntysh. Science \& Technique. 16(2) 931(2017)

3. A.E. Zakharevich. Science \& Technique. 15(6), 940, (2016)

4. A.M. Prishchenko, T.V. Zhmykhova, M.V. Tymofieiev. Budivelni konstruktsii. 79, 16 (2013)

5. A.N. Pryshchenko Visnyk Donbaskoi natsionalnoi akademii budivnytstva i arkhitektury. 2, 13, (2014)

6. G. Vasilyev, V. Leskov, V. Gornov, V. Lichman, M. Kolesova, A. Dmitriev. MATEC Web of Conf. 40, 05004 (2016)

7. O.I. Yurin, T.A. Galinska, M.V. Levchuk Doslidzhennia temperaturnykh poliv zovnishnikh kutiv karkasno-monolitnykh budivel. Zbirnyk naukovykh prats studentiv budivelnoho fakultetu PoltNTU imeni Yuriia Kondratiuka 87 (2013)

8. O.V. Semko, O.I. Yurin Academic journal Series: Industrial Machine Building, Civil Engineering 4(2), 182, (2013) 